\title{
Lying behaviour of group-housed horses in different designed areas with rubber mats, shavings and sand bedding
}

\author{
Miriam Baumgartner', Margit H. Zeitler-Feicht', Anna-Caroline Wöhr², Heike Wöhling² and Michael H. Erhard² \\ 1 Chair for organic agriculture; Work group "Applied Ethology, Animal Husbandry and Animal Welfare; Life Science Center Weihenstephan; Technical University \\ of Munich \\ ${ }^{2}$ Chair of animal welfare, ethology, animal hygiene and animal husbandry of the Veterinary Faculty; Ludwig-Maximilians-University Munich
}

\begin{abstract}
Summary: One of the biggest concerns about group housing of horses is insufficient or interrupted lying behaviour, which might lead to sleep deprivation, and as a consequence thereof reduced performance and health. To address this concern the lying behaviour of 56 horses in a modern group housing system over four seasons was studied. This paper focuses on the lying behaviour of horses on different bedding materials. The reason behind is that rubber mats instead of natural bedding material have recently found an increase in the lying areas of group housings. Previous studies showed a reduced daily lying time on pure rubber mats. Therefore investigations were made on the lying behavior on sponge-filled rubber mats $\left(7.5 \mathrm{~cm}\right.$ in height, HIT-Softbed ${ }^{\circledR}$ plus) in combination with a minimal amount of shavings (ca. $1 \mathrm{~cm}$ in height) and additional lying materials such as pure shavings (ca. $15 \mathrm{~cm}$ in height), both in three lying halls, sand in a shelter and sand in an open paddock. A particular concern of the study was, if rubber mats in combination with a minimum amount of shavings meet the horses demands as bedding material and provide a good stable climate. Moreover we investigated: preferences for different lying areas, individual differences in lying behaviour, influence of lying space, horses rank, daytime, and interruptions by group members. The mean daily total lying time per horse was significantly the longest on shavings (74.3 \pm 2.87 minutes) and rubber mats (62.3 \pm 2.27 minutes) both in the halls (in total 91.1 \pm 2.7 minutes allocated on $3.2 \pm 0.1$ lying bouts) followed by sand bedding in the shelter ( $43.0 \pm 2.33$ minutes) and sand in the open paddock ( $26.7 \pm 2.93$ minutes). Despite horses laid down the longest in the lying halls, the shelter with sand was used more per surface area for resting recumbent, especially by low-rank horses. Hence, shelter is recommendable as an additional lying surface in group housings. No more than $50 \%$ of the horses laid down simultaneously, although the lying space met the minimum requirement of the guidelines with $3 \times$ wither height $^{2}$ per horse (FMFAC 2009). A more diverse number of horses used the biggest lying hall for recumbency more often and for a longer daily period than the two smaller lying halls. Furthermore $32.7 \%$ of the horses did not lie down every day. The horses of low rank showed a significantly shorter length (69.31 \pm 3.9 min per horse per day) and a lower number of lying bouts $(2.58 \pm 0.1$ per horse per day) when compared to horses of higher rank $(90.9 \pm 4.5$ min high rank and $92.7 \pm 3.6$ min middle rank with $3.35 \pm 0.1$ and $3.12 \pm 0.1$ lying bouts per horse per day). Previous studies showed no differences in daily lying time if the lying space is twice the guidelines (FMFAC 2009). Therefore a lying space $6 \times$ wither height $^{2}$ per horse is advisable for group-housed horses. Horses laid down synchronously and with $71.8 \%$ of lying bouts ( $N=1730$ of 2410$)$ mainly between midnight and 6 a.m. Non-eatable bedding material instead of straw only lead to $16.5 \%$ interrupted lying bouts by group members, because foraging horses cannot disturb resting horses. Rubber mats with a minimum amount of shavings have no negative effect on stable climate. Crucial are: good ventilation and manure removed multiple times a day. In conclusion, horses accept rubber mats as a bedding material if they are at least minimally covered with natural bedding materials such as shavings. Group housing systems, which offer the choice between shavings, rubber mats covered with shavings, a shelter with sand and a sand paddock, can be qualified as suitable for horses in terms of animal welfare.
\end{abstract}

Keywords: horse / group housing / lying bouts / recumbency behavior / bedding material / rubber mats / rank / stable climate

Citation: Baumgartner M., Zeitler-Feicht M. H., Wöhr A.-C., Wöhling H., Erhard M. H. (2015) Lying behaviour of group-housed horses in different designed areas with rubber mats, shavings and sand bedding. Pferdeheilkunde 31, 211-220

Correspondence: Dr. Miriam Baumgartner, Technische Universität München, Lehrstuhl für Ökologischen Landbau, Arbeitsgruppe "Ethologie, Tierhaltung und Tierschutz, Liesel-Beckmann-Str. 2, 85354 Freising, Germany, email: m.baumgartner@tum.de

\section{Introduction}

Group housings for horses have recently found an increase, because of obvious advantages for their physical and mental well-being. Recent studies helped to support this trend by minimizing injuries caused by social conflicts between nonfamiliar horses. To name but a few Flauger and Krüger (2013) highlight the importance of spacious enclosure size and Jørgensen et al. (2011) state the supply with roughage. Hereby both study groups observed a reduction of aggressive behavior. Another issue with housing horses in groups is insufficient or interrupted lying behaviour which might lead to sleep deprivation. To address this concern recent studies pointed out the positive effect on the lying behaviour of noneatable bedding material in the lying areas of group housings for horses. Foraging horses cannot disturb recumbent horses, if roughage is offered outside the lying area (Zeitler-Feicht, 2004, Fader 2002).

As a result the equine industry recently launched rubber mats as non-eatable bedding material in group housing systems. The deformable rubber mats are provided with either a system of air chambers or cellular sponge fillings and are supposed to closely resemble the traditional soft bedding. In the field they became an economically very popular alternative to natural bedding materials like shavings in the lying area of group housings. However, Zeitler-Feicht and Muggenthaler (2013) reported significantly shortened recumbency behaviour on rubber mats if horses are not familiar with it for mul- 
tiple years. This paper describes the lying behaviour of 56 horses on rubber mats combined with minimal use of shavings in a follow-up study. A particular concern of our study was if deformable rubber mats in combination with a minimum amount of shavings meet the horses demands as bedding material compared to shavings to a height of circa 15 $\mathrm{cm}$ and provide a good stable climate.

Moreover the aim of the study was to find out certain aspects of lying behaviour of horses in a modern group housing system: individual differences in the lying behaviour and preferences for different lying areas including lying halls with rubber mats, combined with minimal use of shavings, shavings alone, a shelter with sand or a sand paddock. Additional parameters, which might influence the lying behaviour, were also taken into account. These parameters consisted of the lying space, the horses rank, daytime, and interruptions by group members.

\section{Animals, Material and Methods}

\section{Experimental design}

The recumbency behaviour of 56 horses kept together in one group housing system with areas of different bedding materials was documented over four seasons using wide-angle video cameras. The weather conditions varied from snowy and cold to dry and hot (from $-11^{\circ} \mathrm{C}$ in wintertime up to $30^{\circ} \mathrm{C}$ in summertime). At the beginning of the experiment, 46 horses had been living in the stable for a minimum of one year and a maximum of three years, and were thus familiar with the floor coverings. The exception was ten horses, which had only been integrated into the herd a maximum of six months prior to testing.

\section{Animals, housing and management}

The horses differed in age $(13.3 \pm 0.7$ years; range 5 to 26 years), gender (41 geldings and 14 mares) and were mainly warmbloods (52 warmbloods, two Haflingers, one thouroughbred and one Criollo). All horses were only in light work and primarily used for leisure riding. The enclosure size accessible $24 / 7$ amounted $180 \mathrm{~m}^{2}$ per horse. Additionally $2.000 \mathrm{~m}^{2}$ pasture per horse was available dependent on the weather condition.

14 automatic feeding stations (12 HIT Hay Dispenser "Exclusive" and 2 HIT Concentrates Station "Compact") supplied the 56 horses of the present study with hay, haylage, concentrates and minerals. The amount and frequency of forage was individually defined and electronically recorded on transponders, which were implanted in the horses ' neck. Additionally four straw racks provided a permanent access to roughage. Five different areas in the test stable offered three different bedding materials (see table 1).

Each of the three identically designed halls had a centrally positioned space covered with rubber mats (HIT Horsebed Premium). The rubber mats consisted of soft rubber on the surface filled with cellular foam to a height of $7.5 \mathrm{~cm}$. They were minimally covered with shavings to a height of ca. $1 \mathrm{~cm}$. The paved periphery was ca. 2 metres in width and covered

Fig. 1 Interior views of one of the three identically designed halls

Innenansichten von einer der drei identisch ausgestatteten Liegehallen
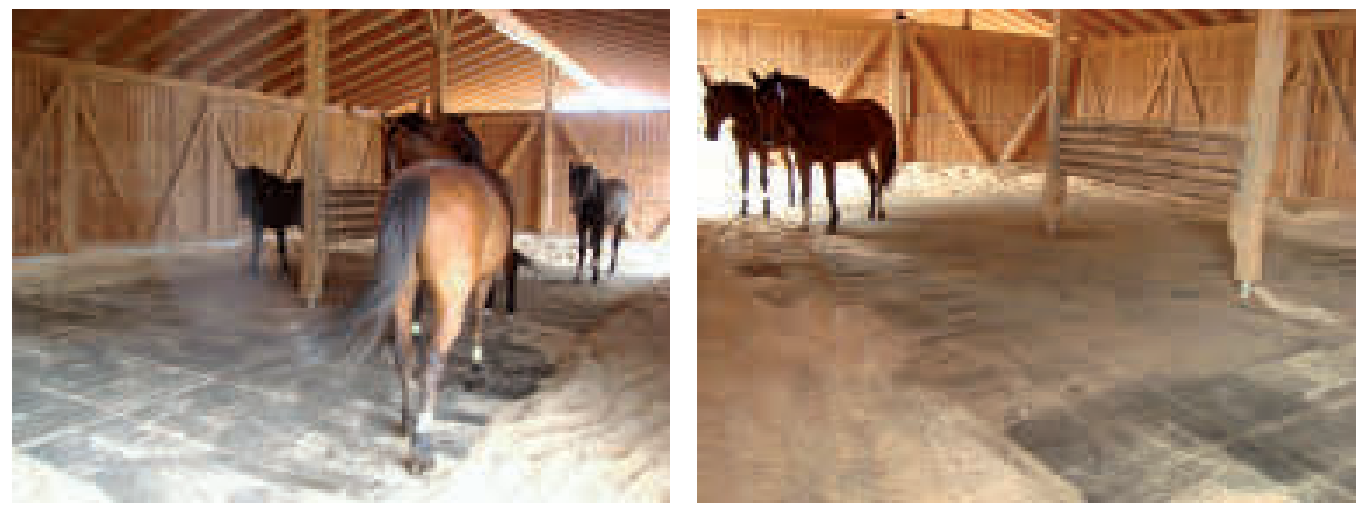

\begin{tabular}{|c|c|c|c|}
\hline \multirow[b]{2}{*}{ Area } & \multirow[b]{2}{*}{ Bedding material } & \multicolumn{2}{|c|}{ Size in $\mathrm{m}^{2}$} \\
\hline & & each & $\begin{array}{l}\text { length } \mathrm{x} \text { width } \\
\text { total (rounded) }\end{array}$ \\
\hline \multirow{2}{*}{ Hall I } & 1. Rubber mats with a minimum amount of shavings & 91 & $18.5 \times 9.3$ \\
\hline & 2. Shavings & 81 & 172 \\
\hline \multirow{2}{*}{ Hall II } & 1. Rubber mats with a minimum amount of shavings & 74 & $15.4 \times 9.3$ \\
\hline & 2. Shavings & 69 & 143 \\
\hline \multirow{2}{*}{ Hall III } & 1. Rubber mats with a minimum amount of shavings & 74 & $15.4 \times 9.3$ \\
\hline & 2. Shavings & 69 & 143 \\
\hline Shelter & Sand & & $\begin{array}{c}30 \times 2.7 \\
81\end{array}$ \\
\hline Sand paddock & Sand & & $\begin{array}{c}\text { ca. } 32 \times 25 \\
800\end{array}$ \\
\hline
\end{tabular}



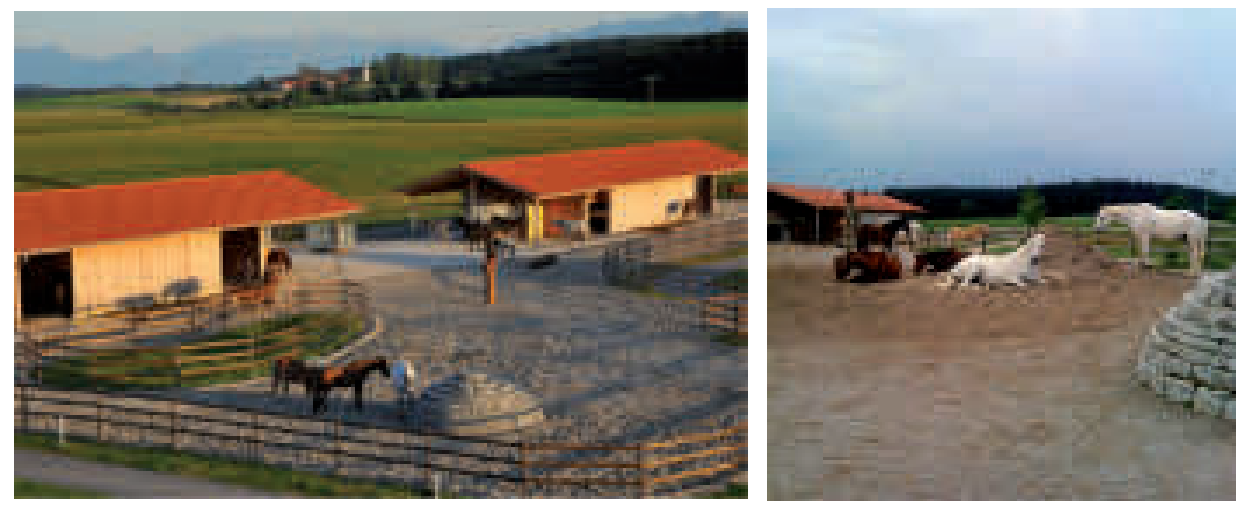

Fig. 2 Left: Bird's eye view of the sand paddock with hall I and II visible; right: Sand paddock with horses resting. (left: Christian Mainzl)

Links: Vogelperspektive des Sandauslaufs mit Liegehalle I und II im Blickfeld; rechts: Sandauslauf mit ruhenden Pferden (links: Christian Mainzl) with shavings to a height of circa $15 \mathrm{~cm}$ (see fig. 1). In the middle of each hall a transparent partition made of wood was erected to subdivide the space (see fig. 1). The total bedding area including shavings and rubber mats met the official guidelines of the federal ministry of Germany (BMELV 2009) with $3 \times$ wither height ${ }^{2}$ per horse $\left(8.2 \mathrm{~m}^{2}\right.$ per horse with wither height of $1.65 \mathrm{~m}$ complies $458 \mathrm{~m}^{2}$ for the three halls/ 56 horses $=8.2 \mathrm{~m}^{2}$ per horse). To reduce urination in the halls three excretion areas were stationed right in front of each hall. The two entrances (ca. $3 \mathrm{~m}$ width) were curtained with plastic strips functioning as wind deflectors. Additionally to the halls, a shelter with sand footing and an unsheltered area with sand footing (sand paddock) also could be used by the horses to lay down (see table 1 and figure 2 and 3). The sand in the present study was round-grained with high water permeability due to its low clay percentage. Manure was removed in the entire group-housing twice a day. Mucking out the three lying halls and the shelter took up 40 minutes on average for one person per day.
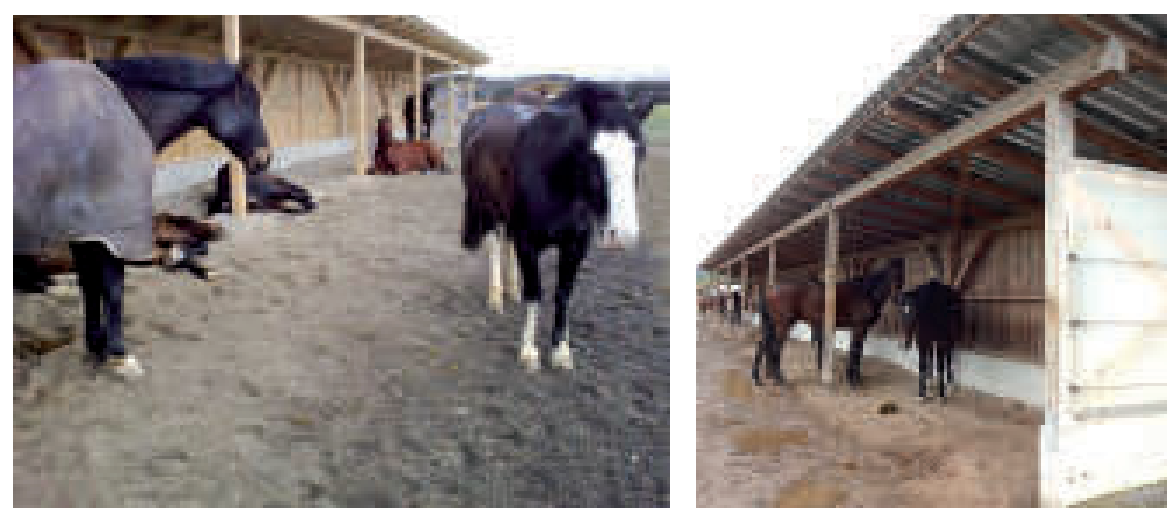

Behaviour recording

The aim of the study was to discover for how long (daily total lying time and duration of lying bouts) and how often (number of lying bouts) the horses were resting in recumbent positions in the different areas (hall I, II and III, sand paddock and shelter) as well as the sub-areas in the halls (Shavings or Rubber mats combined with minimal use of shavings). A lying bout was defined as a period of recumbency, which starts with the act of lying down and ends with the act of standing up again.

To figure out preferences for different lying areas, the relation of areas of different sizes (see table 1) to their use as lying surfaces was compared using their capacity. The capacity is defined as the maximal number of horses able to lie down simultaneously on an available space. The ratio of lying bouts to capacity was used to determine which areas were most popular as lying surfaces.

Fig. 3 Different perspectives of the shelter with horses resting (left: Christian Mainzl)

Verschiedene Perspektiven des Unterstandes mit ruhenden Pferden (links: Christian Mainzl)

\section{Method of examination}

Data were collected continually via video surveillance using 10 wide-angle cameras and five LED-infra-red projectors distributed on the five monitored areas. Per season (spring, summer, autumn, winter) six randomly chosen 24 -hour days were monitored. The observation days in this study were bundled in groups of 2 consecutive days for reasons of practicality. Additionally, 60 hours direct on-site observations during days and nights were conducted. This helped to determine whether the horses also used those areas to lie down which were not captured on video camera. The horses were labelled individually with reflective gaiters and collars with scotchlite-stripes in order to identify the 56 horses on the videos during the night (see fig. 4).
Influence of rank and daytime on lying behaviour and interruptions by group members

Consideration was given to the question if horses of different rank differ in lying behaviour and if horses high in rank preferred certain areas as opposed to those horses with low rank. The number and length of lying bouts was evaluated, depending on the various level of rank.

The aggressive and submissive behaviour of the 56 horses was observed to determine a rough rank order. These were calculated with the help of the "Average Dominance Index" (ADI, Hemelreijk et al. 2005), which was modified for the study at hand. The horses were subdivided into three rank order sections according to their ADls (high rank $n=14$ horses; middle rank $=19$ horses; low rank $n=23$ horses). 
Per 2-hour intervals it was furthermore examined whether certain time periods within the space of a 24-hour day were preferred for lying down. Also, interruptions by group members were investigated in order to find out how often the horses quit recumbency behaviour unwillingly. Furthermore the stable climate in all three halls was measured to gain insight into the hygienic status of rubber beddings. On 10 test days over one year the following parameters were measured at seven different fixed control points with a distance of circa $20 \mathrm{~cm}$ to the ground: ammonia content, air velocity, air humidity and temperature. The measurement values were compared to the values in the FMFAC guidelines (2009) (see table 2).

\section{Data Collection and Statistical Analysis}

To access the results of lying bouts and weather conditions, a separate database was created with Microsoft Access. The statistical analysis was processed via the program SAS version 9.2. The analysis was conducted purely descriptive with the help of tables. Categorical variables were described through frequency $(\mathrm{N})$ and percentages. Continuous variables were described through mean, standard error of mean (SEM), minimum (min) and maximum (max). Following statistic tests supported the descriptive analysis of the hypotheses: A Kruskal-Wallis test was used to analyse the effect of different areas and the three different halls on the total lying time, the number and duration of lying bouts and the influence of rank. The regression model showed the influence of areas, individual horses and the interaction of both on the duration of lying bouts. Differences between lying behaviour on rubber mats and shavings were tested with the Mann-Whitney- $U$ test and the Binomial test (two-sided). The Chi-square test was used to compare frequency distributions. A p-value counted as statistically significant when it was smaller than 0.05 .

\section{Results \\ Influence of the area on the lying behaviour}

Although the lying space met the guidelines with $3 \times$ wither height $^{2}$ per horse (BMELV 2009) only $50 \%$ of the horses laid down simultaneously. It became apparent that related to the capacity of the lying surface the biggest hall $(\mathrm{HI})$ was the most popular one with 37.4 lying bouts per capacity, followed by $\mathrm{H}$ III with 34.4 and H II with 31.3 lying bouts per capacity. In addition a more diverse number of 44 horses used $\mathrm{H}$ I as opposed to a number of 40 different horses, which used the smaller halls (II and III). The same outcome shows the mean number of lying bouts and the total lying time per horse per day. In the biggest hall $(\mathrm{HI})$ the horses rested recumbent more often (H I 2.6 as opposed to HII 2.1 and HIII 2.3; P < 0.0002) and longer (Median: H I 62 min. compared to 45 min. in H II and 52 min. in $\mathrm{H} \mathrm{III;} \mathrm{P<0.0005).} \mathrm{The} \mathrm{shelter,} \mathrm{however,} \mathrm{was}$ used even more per surface area than all three halls (44.4 lying bouts per capacity). The average duration of lying bouts per day and horse showed a right-skewed distribution. 50\% of lying bouts in the halls lasted between 15 to 40 minutes. Table 3 shows that the longest and the highest number of lying bouts per horse per day were marked in the halls followed by the shelter and the sand paddock (each $\mathrm{P}<0.001$ ).

Fig. 4 Flashing reflective gaiters by night to differentiate each horse individually (Video footage of hall I and II with horses resting) Leuchtende Reflexgamaschen zur Identifizierung der Pferde bei Nacht (Videomaterial von Liegehalle I und II mit ruhenden Pferden)
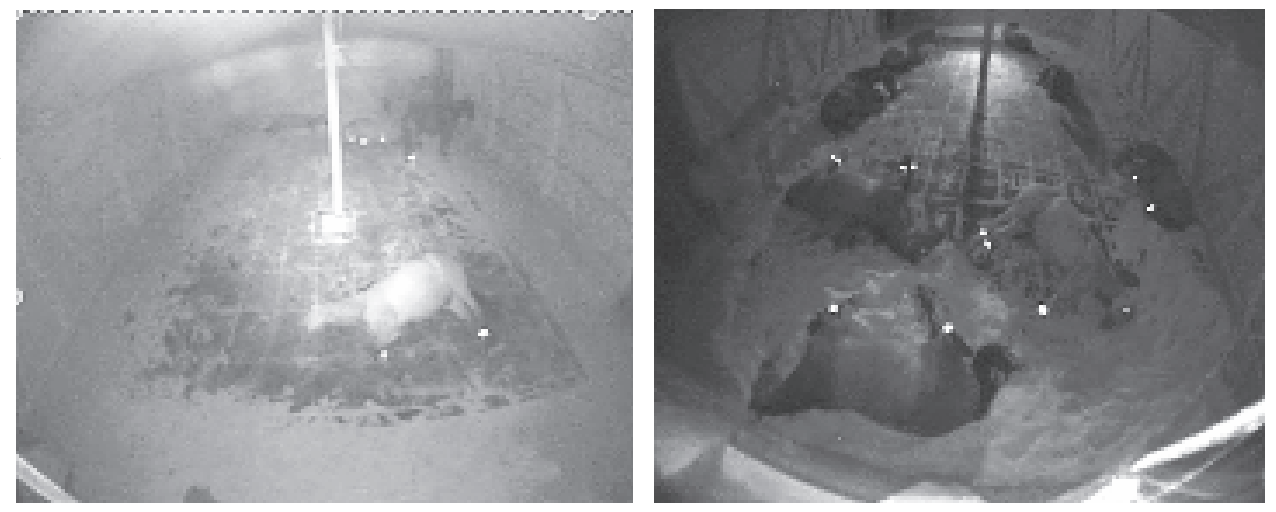

Table 2 Indicative values with regard to FMFAC guidelines (2009) for stable climate conditions / Richtwerte für die Anforderungen an das Stallklima gemäß den Leitlinien des BMELVs (2009)

\begin{tabular}{|c|c|c|c|c|c|c|c|}
\hline Air velocity & & & \multicolumn{5}{|c|}{$\geq 0.2 \mathrm{~m} / \mathrm{s}$} \\
\hline Temperature & \multicolumn{7}{|c|}{ Needs to correlate with outdoor temperature of daily and annual circumstances, with avoidance of extreme values } \\
\hline Humidity & & & \multicolumn{5}{|c|}{$60-80 \%$} \\
\hline Ammonia content (NH3) & & \multicolumn{6}{|c|}{$\leq 10 \mathrm{ppm}$ (Transgressions only for a short time and as an exception) } \\
\hline \multicolumn{8}{|c|}{$\begin{array}{l}\text { Table } 3 \quad \text { Lying behaviour in the different areas per horse per day ( } N=2410 \text { lying bouts of } 54 \text { different horses on } 24 \text { observation days) } \\
\text { Liegeverhalten in den unterschiedlichen Arealen pro Pferd pro Tag ( } N=2410 \text { Liegephasen von } 54 \text { Pferden an } 24 \text { Beobachtungstagen) }\end{array}$} \\
\hline \multirow{2}{*}{ Areas } & \multirow{2}{*}{$\begin{array}{l}\text { Duration of lying bouts in min. } \\
\qquad(\text { mean } \pm \text { SEM) }\end{array}$} & \multirow{2}{*}{$\begin{array}{l}\text { Number of lying bouts } \\
\qquad(\text { mean } \pm \text { SEM) }\end{array}$} & \multicolumn{5}{|c|}{ Total lying time in min. } \\
\hline & & & mean & Median & SEM & $\min$ & $\max$ \\
\hline Halls $(I, I I, I I I)$ & $28.8 \pm 0.5$ & $3.2 \pm 0.1$ & 91.1 & 81.00 & 2.69 & 1.0 & 384.0 \\
\hline Shelter & $24.6 \pm 0.9$ & $1.7 \pm 0.1$ & 43.0 & 32.00 & 2.33 & 1.0 & 238.0 \\
\hline Sand paddock & $20.0 \pm 1.9$ & $1.3 \pm 0.1$ & 26.7 & 23.00 & 2.93 & 2.0 & 78.0 \\
\hline
\end{tabular}


Influence of the sub-areas in the halls on the lying behaviour

The horses used the sub-areas almost the same to rest recumbent (duration of lying bouts $\mathrm{P}=0.093$; number of lying bouts $P=0.064)$. The allocation of the 1903 lying bouts in $\mathrm{H}$ I, II and III on either Shavings (49\%) or Rubber mats with a minimum amount of shavings (51\%) also differed only marginally $(P=0.41)$. However, the daily total lying time per horse was significantly longer on Shavings as opposed to Rubber mats with shavings covered $(P=0.005)$ (table 4$)$.

\section{Lying behaviour of individual horses}

An average number of 35.2 out of 52.3 in the test stable mean present horses (67.3\%; range: $23-40$ horses) laid down in the monitored areas on any given 24-hour observation day. Figure 5 demonstrates the strong dependency of lying bouts on the individual horse. The mean value was exceeded by the median values of only a few horses. It points to a disproportionate allocation of lying bouts of individual horses over the entire test period. The duration of lying bouts varied significantly between horses and areas $(P=0.028)$, as well as between the individual horses $(P<0.001)$. In total 49 different horses of all 54 horses were observed recumbent in the halls. Two horses could only be observed recumbent in the shelter or in the sand paddock and another three horses only used the sand paddock to lie down. Two horses could have never been observed recumbent.
Influence of rank on the lying behaviour

The horses which were lower in rank $(\mathrm{N}=23)$ showed a lower number of $2.58 \pm 0.1$ lying bouts per horse and day as opposed to $3.35 \pm 0.1$ and $3.12 \pm 0.1$ in the two higher rank groups $(N=33 ; P<0.001)$. Additionally, they showed a circa 20 minutes shorter daily total lying time with $69.31 \pm 3.9 \mathrm{~min}$ as opposed to the upper two rank groups $(90.9 \pm 4.5 \mathrm{~min}$ high rank and $92.7 \pm 3.6$ min middle rank; $\mathrm{P}<0.001)$. The number of lying bouts was measured depending on class of rank in the different Areas ( $\mathrm{HI}, \mathrm{II}, \mathrm{III}$, shelter and sand p.) The horses with low ranks had a lower percentage of lying bouts in the halls compared to the horses with higher ranks as shown in figure 6. In exchange, the low-rank horses used the sand $\mathrm{p}$. and the shelter the most. These differences were significant $(P<0.001)$.

\section{Influence of daytime on the lying behaviour}

The allocation of lying bouts over the course of the 24-hour day showed that the horses were lying down significantly most often between midnight and 6 a.m. (71.8\% of lying bouts; $P<0.001$; see figure 7).

Influence of interruptions by group members on the lying behaviour

The horses quit $16.5 \%$ of all registered lying bouts ( $N=2072$ of total 2410 ) because of group members coming too close.

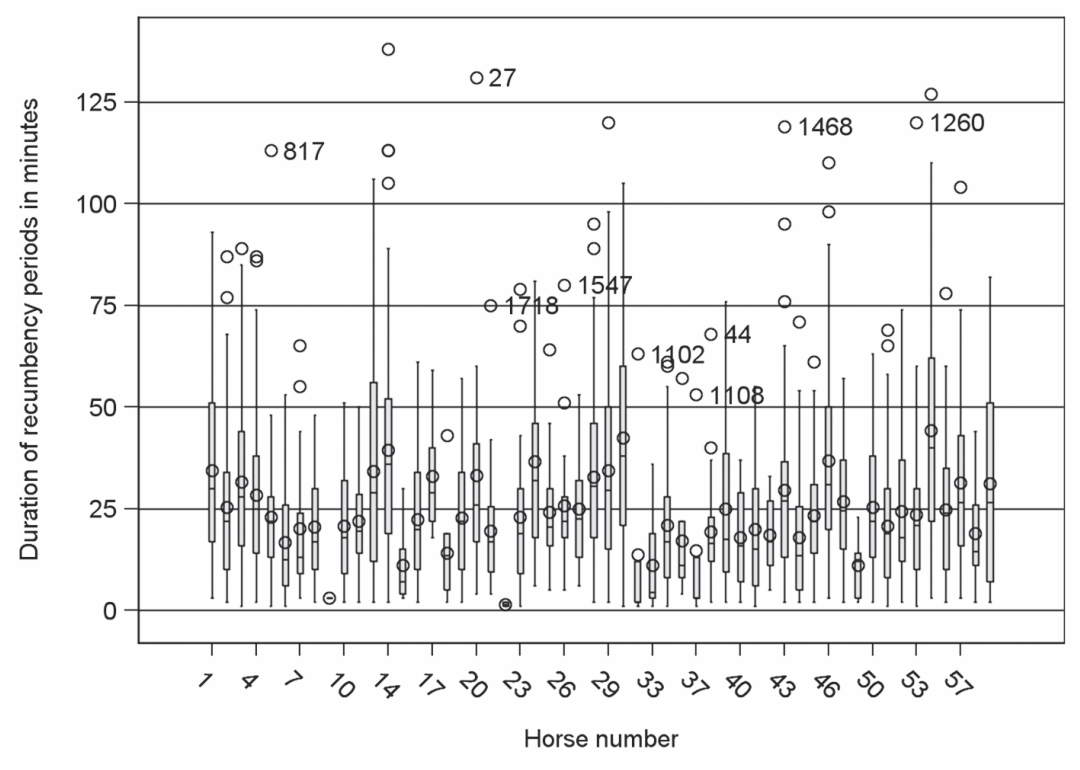

Fig. 5 Daily average duration of lying bouts ( $\mathrm{min}$ ) of individual horses during the observation period ( $N=54$ different horses with numbers up to $59 ; \mathrm{P}<0.001$ ) Abbildung 5: Täglich durchschnittliche Liegephasendaver der individuellen Pferde über die Beobachtungsperiode hinweg $(\mathrm{N}=54$ verschiedene Pferde mit Nummern bis zu 59; $\mathrm{p}<0.001)$

Table 4 Lying behaviour of the sub-areas in the halls per horse per day ( $N=1903$ lying bouts of 49 horses on 24 observation days) Liegeverhalten in den Unterarealen der Liegehallen pro Pferd pro Tag ( $N=1903$ Liegephasen von 49 Pferden an 24 Beobachtungstagen)

\begin{tabular}{|c|c|c|c|c|c|c|c|c|}
\hline \multirow{2}{*}{ Sub-areas } & \multirow{2}{*}{$\begin{array}{l}\text { Number of lying bouts } \\
\text { in total } \\
\text { (percentage) }\end{array}$} & \multirow{2}{*}{$\begin{array}{l}\text { Duration of lying } \\
\text { bouts in min. } \\
\text { (mean } \pm \text { SEM) }\end{array}$} & \multirow{2}{*}{$\begin{array}{c}\text { Number of lying } \\
\text { bouts } \\
\text { (mean } \pm \text { SEM) }\end{array}$} & \multicolumn{5}{|c|}{ Total lying time in min. } \\
\hline & & & & mean & Median & SEM & $\min$ & $\max$ \\
\hline Shavings & 933 (49\%) & $29.5 \pm 0.7$ & $2.4 \pm 0.1$ & 74.3 & 61.00 & 2.87 & 1.0 & 267.0 \\
\hline $\begin{array}{l}\text { Rubber mats with a minimum } \\
\text { amount of shavings }\end{array}$ & 970 (51\%) & $28.0 \pm 0.7$ & $2.2 \pm 0.1$ & 62.3 & 51.00 & 2.27 & 1.0 & 384.0 \\
\hline
\end{tabular}


Fig. 6 Total number and percentage of lying bouts according to rank group in the Areas halls (I, II and III), shelter and sand paddock ( $N=2410$ lying bouts of 54 horses on 24 observation days; $\mathrm{P}<0.001$ ) Gesamtzahl und Prozentsatz der Liegephasen je Rangordnung in den Arealen Liegehallen (I, II und III), Unterstand und Sandauslauf ( $N=2410$ Liegephasen von 54 Pferden an 24 Beobachtungstagen; $p<0.001)$

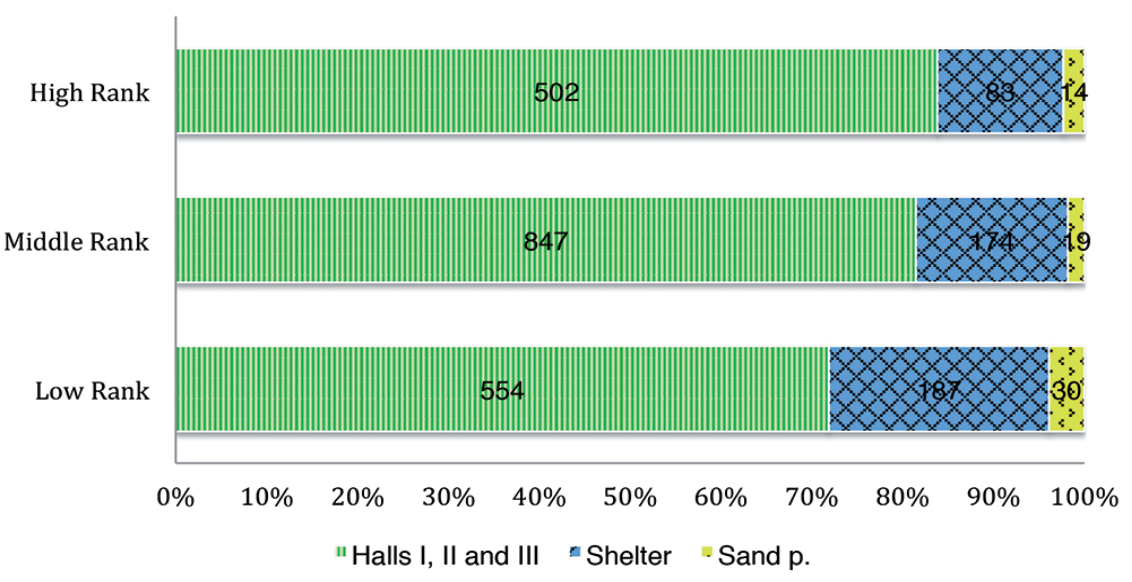

German guidelines for horse husbandries (FMFAC 2009) stipulates $3 \times$ wither height $^{2}$ per horse as a minimum lying space for grouped-housed horses in loose housing systems. The lying halls in our study abided by the minimum lying space. Yet, no more than $50 \%$ of horses laid down simultaneously on the given space. These findings lead to the assumption that the formula for group-housed horses (FMFAC 2009) is stated too small, particularly for large horse groups.

Beside the lying halls an additional lying space was offered: a shelter bedded with sand. The shelter was the most popular when its capacity is taken into consideration. Especially the low-rank horses used the sand paddock and the shelter most for recumbency. Our findings support the recommendations (Zeitler-Feicht 2004) to offer horses held in groups different lying areas, such as a shelter, in addition to lying halls.

The longest and the highest average number of lying bouts per horse per day were marked in the halls followed by the shelter and the sand paddock. The average total daily lying time obtained in the halls (91.1 \pm 2.7 minutes) is similar to previously published values with 102.7 to 112.7 minutes by Zeitler-Feicht and Muggenthaler (2013) for horses in group housings with large lying halls $\left(6 \times\right.$ wither height $\left.^{2}\right)$. Smaller sized lying areas $\left(<2,5 \times\right.$ wither height $\left.{ }^{2}\right)$ lead to shorter daily average lying times (63.0 to 72.3 minutes by Pollmann 2003, Zeitler-Feicht and Prantner 2000).

Influence of the sub-areas in the halls on the lying behaviour

The allocation of the lying bouts on both materials did not differ, but the mean total daily lying time per horse was found to
Fig. 7 Lying bouts in \% according to daytime ( $N=2410$ lying bouts of 54 horses on 24 observation days)

Liegephasen in \% in Abhängigkeit von der Tageszeit ( $N=2410$ Liegephasen von 54 Pferden an 24 Beobachtungstagen))

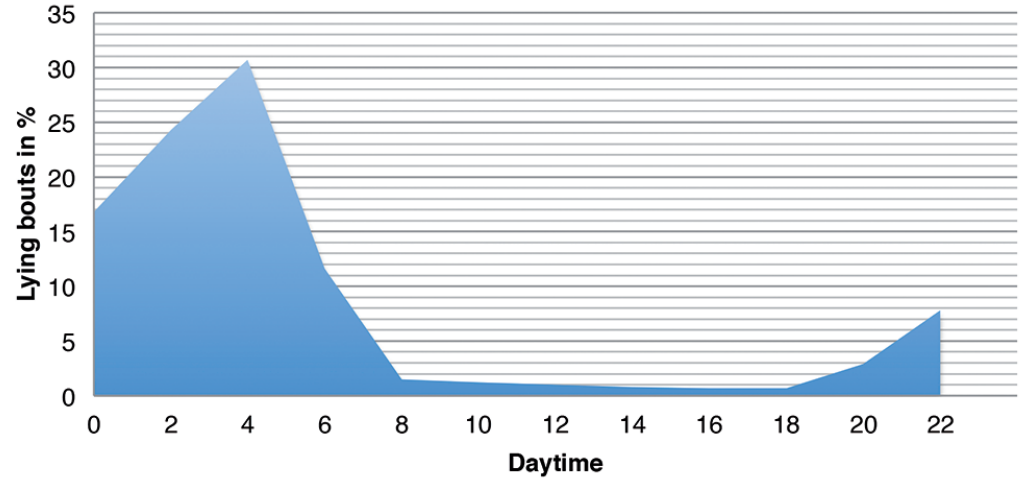


be 12 minutes longer on Shavings (74.3 \pm 2.87 minutes) than on Rubber mats with a minimum amount of shavings $(62.3 \pm 2.27$ minutes). However, both values are in the range of recent studies (63.0 to 86.5 minutes per horse per day) on horses stabled in loose housing systems with shavings or straw bedding (Pollmann 2003, Fader 2002, Zeitler-Feicht and Prantner 2000). Muggenthaler et al. (2010) observed similar lying times on rubber mats with $3 \mathrm{~cm}$ air chambers if the horses had previously known this type of bedding for multiple years. Nevertheless, Muggenthaler et al. (2010) showed in a second study with comparable conditions to our study that horses that were not previously acquainted with rubber mats as a bedding material almost did not lay down on rubber mats $(3.5 \mathrm{~min} /$ horse/day) compared to shavings (76.0 min/horse/day). Zeitler-Feicht (2013) therefore recommends that horses that are previously unacquainted with rubber mats be introduced to the rubber mats in the integration box where shavings are gradually reduced to a minimum amount. Further preference tests are advisable comparing the lying behaviour of horses on rubber mats with and without a minimum amount of non-eatable bedding material. The findings of our study in combination with recent studies lead us to the conclusion that rubber mats must be at least minimally covered with natural lying materials such as shavings.

\section{Lying behaviour of individual horses}

$32.7 \%$ of the horses do not lie down every day. A comparison between different housing conditions showed that horses do not lie down every $24 \mathrm{~h}$ recording period no matter if stabled or yarded (Chaplin and Gretgrix 2010). Güntner (2010) determined $28.6 \%$ of single stabled horses do not lay down, whereas Kalus (2014) observed single stabled horses resting recumbent every night. In group housings even with double the lying area than the guidelines stipulate (FMFAC 2009) some horses do not lay down every 24-hour-day (ZeitlerFeicht and Muggenthaler 2013). Recumbency behaviour of all horses was found to be strongly dependent on the individual horse as reported by Chaplin and Gretgrix (2010). The mean value was always above the median value, which points to the right-sided skew of the values for each individual horse. The need for recumbency seems to vary individually very widely. Since the days of observation in this study were bundled in groups of two consecutive days, it is possible that a regular need for recumbency is not pressing in the horse as suggested by Zeitler-Feicht and Muggenthaler (2013), Wöhr et al. (2011) and Güntner (2010). Two horses that were never observed recumbent were both 26 years old and as such belong to the oldest of the group. Older or sick horses are known to rarely or even never lie down (Zeitler-Feicht 2004, Fader 2002, Houpt et al. 2001).

\section{Influence of rank on the lying behaviour}

An exact order of rank of each horse in the herd could not be determined. This was due to the fact that there were very few rank-determining interactions within the herd. According to Gröngröft (1972), a herd of horses composed of more than 11 animals automatically gets split into multiple smaller subgroups. An order of rank can then not be demonstrated. It was found in this herd of 56 horses that there were multiple clearly high rank and low rank animals, with one gelding being clearly at the top of the hierarchy. High-ranking horses tend to claim the best lying areas and spend up to three times as long in recumbency compared to low-ranking horses (Heintzelmann-Gröngröft 1984). The horses of low rank showed a significantly shorter length $(69.31 \pm 3.9 \mathrm{~min})$ and a lower number of recumbency phases when compared to horses of higher rank $(90.9 \pm 4.5 \mathrm{~min}$ high rank and $92.7 \pm 3.6$ min middle rank). This is consistent with the findings of Fader (2002) who showed reduced or even absent recumbency behaviour of low rank horses in group housing systems. The results in this study did not vary quite as extreme as comparison studies (Muggenthaler et al. 2011 , Fader 2002, ZeitlerFeicht and Prantner 2000). However, if the lying space is twice the guidelines (FMFAC 2009: $3 \times$ wither height $^{2}$ per horse,) the low-rank horses do not differ from high-rank horses in their daily lying time (Zeitler-Feicht and Muggenthaler 2013).

\section{Influence of daytime on the lying behaviour}

Horses do not rest recumbent by turns or all day through. They lie down synchronously and mainly between midnight and 6 a.m. This result correlates well with the literature of free-ranged and stabled horses (Chaplin and Gretgrix 2010, Pederson et al. 2004, Duncan 1980, Keiper and Keenan 1980, Dallaire and Ruckebusch 1974, Steinhart 1937).

Influence of interruptions by group members on the lying behaviour

The horses quit $16.5 \%$ of all registered lying bouts unwillingly because of group members coming too close. This result varies from those obtained in 2002 by Fader. She observed that horses stood up in $44 \%$ of all lying bouts because of disturbances by group members. The reason for that laid in the fact that all test stables were bedded with straw. If bedding is eatable, hungry horses disturb recumbent horses.

\section{Measurements of stable climate in the halls}

According to the german guidelines (FMFAC 2009), certain environmental demands must be met in horse husbandries. In our study the stable environment met these demands in the halls with the combination of rubber mats and shavings. No negative effect on temperature, humidity, air velocity and ammonia content was found. The decisive factors were appropriate ventilation, as well as good stable hygiene through removing manure multiple times a day. Under these conditions our findings confirm that rubber mats in combination with a minimum amount of shavings in group-housing systems with separate functional areas are of no concern to stable hygiene.

\section{Conclusion}

An unregularly and individually different need for recumbency seems to be a normal behavioural pattern in the horse, but further studies should be done on recumbency behaviour of 
horses, especially on rubber mats, in order to assess confounding factors. The bigger the lying surface, the more horses lie down not only more often, but also for longer periods. The formula $3 \times$ wither height $^{2}$ per horse seems to be not enough as a minimum lying space for grouped housed horses in loose housing systems. In accordance to recent studies a lying space twice as big is beneficial for low-rank horses. Furthermore an additional lying area is recommendable, because it is a very popular alternative for resting recumbent, especially for the low-rank horses.

On bedding material, which is not eatable such as shavings or sand, horses abandon only every sixth lying bout because of disturbing group members. In contrast to that they end almost every second lying bout on straw unwillingly. Hence bedding material in group housing systems for horses should not be eatable. Forage should be offered outside the lying areas.

If horses are supposed to accept rubber mats as a bedding material, they should be at least minimally covered with natural bedding materials such as shavings. Rubber mats with a minimum amount of shavings ensure a good stable climate if appropriate ventilation is given and manure is removed multiple times a day. Especially during heavy rain and snowfall, shavings on rubber mats ensure a dry and nonslip lying surface. Under these conditions deformable rubber mats in group housing systems can be considered suitable for horses in terms of animal welfare.

\section{Conflict of interest statement}

The authors exclude any conflict of interest in regard to named or discussed manufacturers resp. technical equipments.

\section{References}

Chaplin S. J., Gretgrix L. (2010) Effect of housing conditions on activity and lying behaviour of horses. Animal 4, 792-795

Duncan P. (1980) Time-Budgets of Camargue Horses 2. Time Budgets of Adult Horses and Weaned Sub-Adults. Behav. J. 72, 26-49

Dallaire A., Ruckebusch Y. (1974) Sleep and wakefulness in the housed pony under different dietary conditions. Can. J. Comp. Med. $38,65-71$

Fader C. (2002) Ausscheide- und Ruheverhalten von Pferden in Offenlaufstall- und Boxenhaltung. Doctoral thesis, Technical University Munich

Flauger B., Krüger K. (2013) Aggression level and enclosure size in horses (Equus caballus) Pferdeheilkunde 29, 495-504

FMFAC guidelines (2009) Leitlinien zur Beurteilung von Pferdehaltungen unter Tierschutzgesichtspunkten (Guidelines on evaluating housing systems for horses with respect to animal welfare). Ed. by the Bundesministerium für Ernährung, Landwirtschaft und Verbraucherschutz (German Federal Ministry of Nutrition, Agriculture and Consumer Protection)

Gröngröft B. (1972) Rangordnung bei Pferden. Doctoral thesis, University of Veterinary Medicine Hannover

Güntner K. U. (2010) Polysomnographische Untersuchung zum Schlafverhalten des Pferdes. Doctoral thesis, Ludwig-MaximiliansUniversity Munich

Heintzelmann-Gröngröft B. (1984) Spezielle Ethologie Pferd. In: Bogner H, Grauvogl A, editors. Verhalten landwirtschaftlicher Nutztiere, Stuttgart: Verlag Eugen Ulmer
Hemelrijk C. K., Wantia J., Gygax L. (2005) The construction of dominance order: comparing performance of five methods using an individual-based model. Behav. J. 142, 1037-1058

Houpt K. A., Houpt T. R., Johnson J. L., Erb H. N., Yeon S. C. (2001) The effect of exercise deprivation on the behaviour and physiology of straight stall confined pregnant mares. Animal Welfare 10, 257-267

Jørgensen G. H. M., Liestø S. H. O., Bøe K. E. (2011) Effects of enrichment items on activity and social interactions in domestic horses (Equus caballus). Appl. Animal Behav. Sci. 129, 100-1 10

Kalus M. (2014) Schlafverhalten und Physiologie des Schlafes beim Pferd auf der Basis polysomnographischer Untersuchungen. Doctoral thesis, Ludwig-Maximilians-University Munich

Keiper R. R., Keenan M. A. (1980) Nocturnal Activity Patterns of Feral Ponies. J. Mam. 61, 116-118

Muggenthaler K., Zeitler-Feicht M. H., Mühlbaver A. C., Kilian E., Reiter K. (2010) Sägespäne versus Liegematten - Untersuchungen zum Ausruh- und Ausscheideverhalten von Pferden in der Liegehalle von Mehrraumaußenlaufställen mit Auslauf. KTBL-Schrift: Aktuelle Arbeiten zur artgemäßen Tierhaltung 482, 145-155

Pederson G. R., Sondergaard E., Ladewig J. (2004) The influence of bedding on the time horses spend recumbent. J. Equine Vet. Sci. 24, 153-158

Pollmann U. (2003) Einfluss der Strukturierung des Liegebereichs einer Gruppenauslaufhaltung auf das Verhalten der Pferde. Tagungsband der DVG-Fachgruppen Tierschutzrecht und Tierzucht, Erbpathologie und Haustiergenetik, 71-75

Obergfell J., Martschuk N., Möbius G., Pollmann U., Wolf H. (2013) Einfluss von Strukturelementen auf das Liegeverhalten von Pferden in Gruppenhaltung unter der Berücksichtigung des Aggressionsverhaltens. KTBL-Schrift: Aktuelle Arbeiten zur artgemäßen Tierhaltung 503, 78-86

Raabymagle P., Ladewig J. (2006) Lying behavior in horses in relation to box size. J. Equine Vet. Sci. 26, 11-17

Steinhart P. (1937) Der Schlaf des Pferdes. Z. Veterinärk. 49, 145-157

Wöhr A. C., Steidele N., Erhard M. (2011) Verhalten von Przewalski-Junghengsten in seminatürlicher Umgebung. KTBL-Schrift: Aktuelle Arbeiten zur artgemäßen Tierhaltung 489, 1-15

Zeitler-Feicht M. H., Prantner V. (2000) Recumbence resting behaviour of horses in loose housing systems with open yards. Arch. Animal Breed. 43, 327-335

Zeitler-Feicht M. H. (2004) Horse Behaviour explained - Origins, Treatment, and Prevention of Problems. Manson Publishing, London

Zeitler-Feicht M. H., Muggenthaler K., Mühlbaver A. C. (2011) Zur Tiergerechtheit von Gummimatten als Liegeunterlage in der Offenstallhaltung von Pferden. Tagungsbericht der Deutschen Veterinärmedizinischen Gesellschaft e.V. (DVG), Fachgruppe Ethologie und Tierhaltung, Gießen: Verlag der DVG Service GmbH: 223-239

Zeitler-Feicht M. H., Muggenthaler K. (2013) Zum Liegeverhalten von Pferden in Gruppenhaltung in Abhängigkeit von der Liegeplatzgestaltung und Rangordnung. Prakt. Tierarzt 94, 420-428

Zeitler-Feicht M. H.(2013) Tiergerechte Haltungsverfahren für Sportund Freizeitpferde gemäß den Leitlinien des BMELV. Pferdeheilkunde $29,476-484$

Erweiterte Zusammenfassung

\section{Liegeverhalten von Pferden auf Gummimatten, Spänen und Sand in unterschiedlich gestalteten Arealen einer Gruppenhaltung}

Die Gruppenhaltung von Pferden erfreut sich in den letzten Jahren zunehmender Popularität; die Vorteile für das physische und mentale Wohlbefinden der Pferde liegen auf der Hand. Aktuelle Studien unterstützen diese Entwicklung in der Pferdehaltung. So betonen Flauger und Krüger (2013), wie wichtig ein großzügig bemessener Auslauf in der Gruppenhaltung ist und Jørgensen et al. (2011) empfehlen eine aus- 
reichende Raufuttervorlage, um aggressive Verhaltensweisen zu reduzieren. Pferde in Gruppen zu halten wird jedoch nicht nur im Hinblick auf das Verletzungsrisiko durch Auseinandersetzungen zwischen den Pferden häufig für bedenklich gehalten, sondern auch in Bezug auf mangelndes Ausruhen im Liegen: Ein gemeinsames Liegeareal könnte zu Benachteiligungen einzelner Pferde führen und damit einhergehend Schlafentzug die Leistung und Gesundheit der Tiere beeinträchtigen. Defizite im Ausruhverhalten in der Gruppenhaltung werden jedoch unter anderem durch Trennung von Ruhe- und Fressbereich verhindert, da fressende Pferde ruhende Artgenossen nicht stören können (Zeitler-Feicht 2004, Fader 2002). Die Pferdeindustrie brachte in Zuge dessen als nichtfressbare Liegeunterlage für Gruppenhaltungen Gummimatten auf den Markt. Diese sind entweder mit Luftkammern oder mit einem Schaumstoffkern gefüllt, wodurch sie den verformbaren Eigenschaften herkömmlicher Liegeunterlagen ähneln sollen. In den Liegearealen von Gruppenhaltungen nehmen Gummimatten in der Praxis, nicht zuletzł aus ökonomischen Gründen, stetig zu. Jedoch stellten Zeitler-Feicht und Muggenthaler (2013) signifikant reduziertes Liegeverhalten auf bloßen Gummimatten fest, wenn die Pferde nicht langiährig damit vertraut sind. Im Fokus vorliegender Studie stand deshalb das Liegeverhalten von Pferden auf unterschiedlichen Liegematerialien in einer modernen Gruppenhaltung (Mehrraum-Außenlaufstall mit Auslauf der Firma HIT-Akitvstall $\left.{ }^{\circledR}\right)$. Über vier Jahreszeiten hinweg wurde das Liegeverhalten von 56 Pferden auf folgenden Liegematerialien erfasst: schaumstoffgefüllte Gummimatten (Höhe 7,5cm, HIT-Pferdebett Premium $\left.{ }^{\circledR}\right)$ in Kombination mit einer geringen Menge an Späneeinstreu (Minimaleinstreu, ca. $1 \mathrm{~cm}$ ), reine Späneeinstreu (ca. $15 \mathrm{~cm}$ ), beide Liegematerialien in drei identisch gestalteten, jedoch unterschiedlich großen Liegehallen und Sand sowohl in einem Unterstand als auch auf einem Paddock (Tabelle 1 sowie Abbildung 1, 2 und 3). Von besonderem Interesse war, ob Gummimatten mit Minimaleinstreu den Ansprüchen von Pferden an eine Liegeunterlage gerecht werden und ein gutes Stallklima gewährleisten (Tabelle 2). Darüberhinaus wurde untersucht: Präferenzen für bestimmte Liegeareale, individuelle Unterschiede im Liegeverhalten, der Einfluss der zur Verfügung stehenden Liegefläche, der Einfluss der Rangordnung und der Einfluss der Tageszeit sowie durch Herdenmitglieder unterbrochene Liegephasen.

Die tägliche Gesamtliegedaver pro Pferd war signifikant am längsten auf Späne (74,3 $\pm 2,87$ Minuten) und Gummimatten $(62,3 \pm 2,27$ Minuten) in den Liegehallen (insgesamt 91,1 $\pm 2,7$ Minuten verteilt auf 3,2 Liegephasen) gefolgt von Sand als Liegeunterlage im Unterstand (43,0 $\pm 2,33$ Minuten) und Sand im Auslauf $(26,7 \pm 2.93$ Minuten; Tabelle 3 und 4). Obwohl sich die Pferde in den Liegehallen am längsten zum Ruhen hinlegten, suchten sie zum Liegen den Unterstand mit Sand in Flächenrelation häufiger auf, insbesondere rangniedere Pferde (Abbildung 6). Die Liegefläche entsprach mit $3 \times$ Widerristhöhe ${ }^{2}$ den Mindestanforderungen der Leitlinien (BMELV 2009). Es lagen jedoch nie mehr als 50\% der Pferde gleichzeitig auf der zur Verfügung stehenden Liegefläche. Des Weiteren legten sich 32,7\% der Pferde nicht täglich zum Ruhen nieder. Das Liegeverhalten der Pferde erwies sich als stark vom individuellen Pferd abhängig. Der Mittelwert der Liegedaver lag größtenteils über dem Median, was auf eine rechtsschiefe Verteilung der Liegedauer des individuellen Pferdes hinweist (Abbildung 5). So variierte die Liegephasendaver signifikant zwischen den Pferden und den Arealen $(P=0,028)$, aber auch je Pferd über den Beobachtungszeitraum hinweg $(P<0,001)$. In der größten der drei Liegehallen lagen die Pferde häufiger und länger pro Tag. Zudem nutzen mit 44 unterschiedlichen Pferden mehr Tiere die größere Liegehalle im Vergleich zu jeweils 40 unterschiedlichen Pferden in den zwei kleineren, identisch bemessenen Liegehallen. Rangniedere Pferde zeigten signifikant weniger $(2,58 \pm 0,1$ pro Pferd und Tag) und kürzere Liegephasen $(69,31 \pm 3,9$ Minuten pro Pferd und Tag) im Vergleich zu ranghöheren Pferden (90,9 $\pm 4,5$ Minuten der ranghohen Pferde und $92,7 \pm 3,6$ Minuten der Pferde mittleren Rangs mit $3,35 \pm 0,1$ and $3,12 \pm 0,1$ Liegephasen pro Pferd und Tag). Die Pferde legten sich synchron und mit 71,8\% $(n=1730)$ aller Liegephasen ( $n=2410)$ zum Ruhen im Liegen überwiegend zwischen Mitternacht und 6 Uhr morgens nieder (Abbildung 7). Auf nichtfressbarer Einstreu unterbrachen sie aufgrund Störungen durch Herdenmitglieder lediglich jede 6 . Liegephase (16,5\% der Liegephasen). Im Gegensatz dazu beendeten Pferde auf Stroh fast jede 2. Liegephase unfreiwillig (Fader 2002).

Ein unregelmäßiges und individuell unterschiedliches Liegebedürfnis scheint nach vorliegender Studie ein normales Verhalten bei Pferden zu sein. Jedoch wären weitere Untersuchungen zum Liegeverhalten von Pferden sinnvoll, insbesondere weitere Wahlversuche auf Gummimatten. Entspricht die Liegefläche dem Doppelten der Mindestanforderungen (BMELV 2009), zeigen die Pferde von unterschiedlichem Rang keine signifikanten Unterschiede im Liegeverhalten (ZeitlerFeicht und Muggenthaler 2013) im Gegensatz zu den Ergebnissen vorliegender Untersuchung. Auch eine Maximalauslastung der Liegefläche von lediglich $50 \%$ an gleichzeitig liegenden Pferden deutet darauf hin, dass eine Liegefläche von $3 \times$ Widerristhöhe ${ }^{2}$ pro Pferd in der Offenlaufstallhaltung von Pferden zu wenig ist. Gemäß bisheriger Untersuchungen und vorliegender Studie erscheint daher $6 \times$ Widerristhöhe $^{2}$ pro Pferd im Offenlaufstall empfehlenswert. Außerdem empfiehlt es sich in Gruppenhaltungen eine zusätzliche Liegefläche in Form von einem Unterstand anzubieten, da er besonders von rangniederen Pferden zum Liegen gerne angenommen wird. In Gruppenhaltungen ist nicht-fressbare Einstreu als Liegeunterlage von Vorteil; auf Stroh werden erheblich mehr Liegephasen gestört. Raufutter sollte daher außerhalb der Liegeareale zur Verfügung stehen.

Schlussfolgernd lässt sich feststellen, dass Gummimatten in Gruppenhaltungen von Pferden angenommen werden, wenn sie zumindest minimal mit natürlichen Liegematerialien wie Sägespänen bedeckt sind. Bei Starkregen oder Schneefall garantiert Einstreu auf Gummimatten zudem eine trockene und rutschfeste Liegefläche. Gummimatten mit Minimaleinstreu beeinflussen das Stallklima nicht negativ, vorausgesetz eine gute Durchlüftung und täglich mehrmaliges Entmisten ist gegeben. Ein Gruppenhaltungssystem, in dem Pferde ihr Liegebedürfnis auf reiner Späneeinstreu, mit Späne überstreuten, verformbaren Gummimatten, auf Sand in einem Unterstand und in einen Sandauslauf stillen können, kann bezüglich des Liegeverhaltens als tiergerecht bezeichnet werden.

Schlüsselwörter: Pferd / Gruppenhaltung / Liegezeit / Liegeverhalten / Einstreu / Gummimatten / Rangordnung / Stallklima 